\title{
Characterization of free-living and attached bacteria in sediments colonized by Hediste diversicolor
}

\author{
Françoise S. Lucas ${ }^{1, *}$, Georges Bertru' ${ }^{2}$, Manfred G. Höfle ${ }^{3}$ \\ ${ }^{1}$ Institute of Ecology, University of Lausanne, 1015 Lausanne, Switzerland \\ ${ }^{2}$ UMR 6553, Université de Rennes 1, Avenue du Général Leclerc, 35042 Rennes Cedex, France \\ ${ }^{3}$ GBF-German Research Center for Biotechnology, Department of Environmental Microbiology, Mascheroder Weg 1, \\ 38124 Braunschweig, Germany
}

\begin{abstract}
The dynamics of free-living and attached bacteria populations were studied in salt marsh sediments that were extensively colonized by the polychaete Hediste (Nereis) diversicolor (O. F. Müller). Bioturbation by $H$. diversicolor affected the density and community structure of free-living (FLB) and attached (AB) bacteria assemblages. Passage through the polychaete gut resulted in an 81 to $88 \%$ decrease of both bacterial groups and shift in favor of FLB in the hindgut (HG). In surficial sediments outside and inside the worm bed, attached bacteria represented 77 to $99 \%$ of the total bacterial densities. Although FLB were minor in terms of biomass, their densities strongly increased in January and May and peaked from 9.6 to $16.2 \times 10^{8}$ cells $^{-1}$. AB peaked in August and October with densities from 205.8 to $283.6 \times 10^{8}$ cells $\mathrm{g}^{-1}$. AB densities were significantly higher in burrow wall sediment than in surrounding sediment. The density of FLB and AB was reduced in surficial sediment inside the worm bed compared to sediments not colonized by $H$. diversicolor. Community fingerprints of environmental 5S rRNA showed that there was no significant difference between the structure of the 2 bacterial assemblages. However, in August 1995, the 2 assemblages were highly divergent in the sediment outside the worm bed. The structure of FLB and AB from inside the worm bed was significantly different from the structure of bacterial assemblages outside the sediments colonized by $H$. diversicolor.
\end{abstract}

KEY WORDS: Salt marsh $\cdot$ Sediment $\cdot$ Bioturbation $\cdot$ Polychaete $\cdot$ Bacteria $\cdot 5 \mathrm{~S}$ rRNA Resale or republication not permitted without written consent of the publisher

\section{INTRODUCTION}

During the past decades, research on benthic food webs has focused on the relative importance of detritus versus bacteria in the diet of benthic macrofauna (Lopez \& Levinton 1987), while the effect of macrofauna on the bacterial community has received less attention (Kemp 1990). However, some results indicate that deposit-feeders, such as polychaetes, can either control or stimulate bacterial biomass and activity directly by predation or indirectly by bioturbation (Moriarty et al. 1985, Grossmann \& Reichardt 1991, Reichardt et al. 1991). Studies analyzing how marine deposit-feeders affect microbial variables focused on diverse species of crustaceas, holothurias and mol- luscs. Few reports deal with polychaetes (Aller \& Yingst 1985, Duchene et al. 1988, Reichardt 1988, Plante et al. 1989, Grossmann \& Reichardt 1991, Plante \& Jumars 1993, Steward et al. 1996, Plante \& Shriver 1998, Phillips \& Lovell 1999). Among polychaetes, data dealing with the deposit-feeder and borrowing Hediste (Nereis) diversicolor (O.F. Müller) are scarce. However, this polychaete causes substantial changes in oxygenation and redox potential of surficial and burrow-lining sediments that may have a significant effect on the bacterial assemblages (Esselink \& Zwarts 1989, Gilbert et al. 1994). For instance, denitrification rates increased in surface sediments with $H$. diversicolor colonies and activity of chemolithotrophic bacteria was stimulated in burrows (Gilbert et al. 1994). Lucas \& 
Bertru (1997) demonstrated that $>80 \%$ of ingested sediment bacteria disappeared in the $H$. diversicolor midgut (MG) via bacteriolysis. Lysis in the MG and regrowth in the hindgut (HG) of diverse bacterial strains may occur at different rates, thus altering the bacterial community composition of feces and of surrounding sediments (Plante \& Shriver 1998). However, field studies supporting this hypothesis are needed.

A few studies have examined the impacts of depositfeeding infauna on microbial community structure using either cultivation techniques (Findlay \& White 1983, Duchêne et al. 1988) or analysis of phospholipid fatty acid (PLFA) profiles (Dobbs \& Guckert 1988a,b, Steward et al. 1996, Phillips \& Lovell 1999, Bird et al. 2000). Cultivation techniques have drawbacks because isolates typically represent less than $1 \%$ of natural bacterial communities (Amann et al. 1995). The use of cultivation-independent techniques based on nucleic acid and/or PLFA analyses avoids this bias. However, many of these techniques are time consuming, not quantitative, and sometimes data complexity constitutes substantial challenges for analysis. There is a clear need for methods that can be used to rapidly examine microbial community structure. One simple approach is to separate bacteria into easily recognizable groups such as free-living (FLB) and attached bacteria (AB) (Pedros-Alio 1989). Using molecular techniques, differences in the taxonomic structure between FLB and AB assemblages have been demonstrated in the water column (Delong et al. 1993, Acinas et al. 1999, Crump et al. 1999, Selje \& Simon 2003). PCR-based techniques, such as cloning and DGGE profiles, allow the analysis of dominant species in the total community. While avoiding PCR biases, 5S rRNA

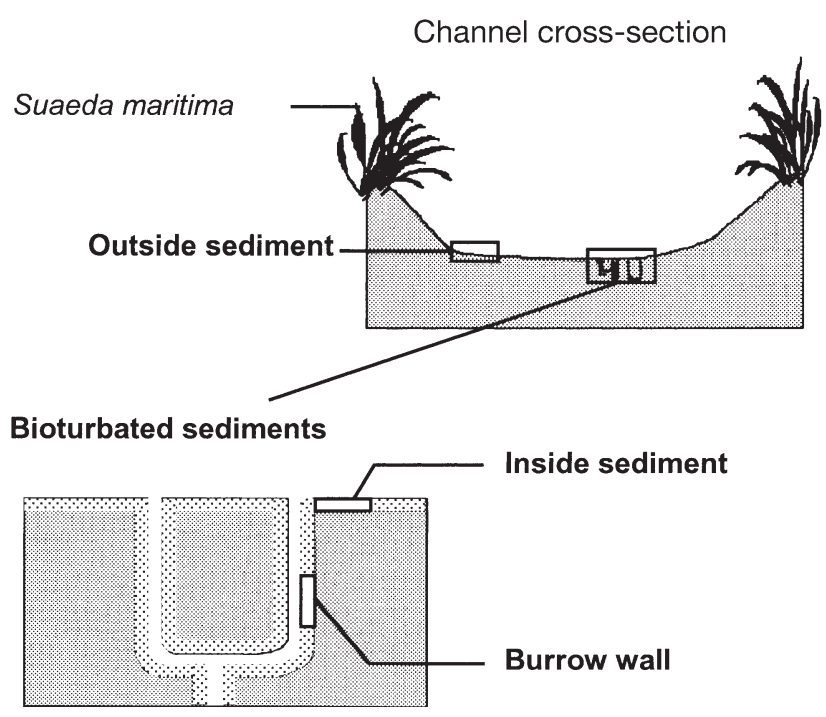

Fig. 1. Hediste diversicolor. Location of outside, inside and wall sediments in the drainage channel profiles directly address the distribution and relative abundance of dominant active members of bacterial community (Höfle 1992), since the amount of RNA is well correlated with the growth rate of bacteria (Kemp et al. 1993). Closely related organisms usually have 5S rRNA of the same size, which allows a resolution at the genus level (Höfle 1992). 5S rRNA analysis has been successfully applied to study the community dynamics of bacterioplankton (Höfle 1992, Bidle \& Fletcher 1995, Höfle et al. 1999).

Developing methods to understand how the polychaete Hediste diversicolor influences bacterial community structure is important as this worm may affect the activity and occurrence of key functional groups within benthic ecosystems. Bacteria in marine sediments control most biogeochemical cycles and benthic food web dynamics (Azam et al. 1983). To understand how lysis and regrowth in the deposit-feeder digestive's tract and bioturbation, resulting from burrowing activity, may affect the structure of bacterial communities, we studied the temporal and spatial distribution and structure of FLB and $\mathrm{AB}$ in gut contents of $H$. diversicolor and in bioturbated sediments. The taxonomic structure of active members of these 2 bacterial groups was directly analyzed using 5S rRNA profiles.

\section{MATERIALS AND METHODS}

Study site. The salt marsh was situated in the Bay of Mont St Michel, France $\left(48^{\circ} 40^{\prime} \mathrm{N}, 1^{\circ} 40^{\prime} \mathrm{W}\right)$. Adult worms $(n=10)$ were collected on October 9, 1995 by digging in a tidal channel. Digestive tracts of 5 worms were divided into $\mathrm{MG}$ and $\mathrm{HG}$, and dissected as in Lucas \& Bertru (1997). Five Hediste diversicolor were also left to fast for $12 \mathrm{~h}$ in order for their feces to be collected. Gut samples and feces from 5 worms were pooled in order to count bacteria in ingested sediments.

Sediment samples were collected in the tidal channel on October 9, 1995 (O95) and January 17, May 23, August 27 and October 4, 1996 (J96, M96, A96, O96, respectively). Surficial sediments were sampled ( $6 \mathrm{~g}$ at 0 to $1 \mathrm{~cm}$ deep): (1) on the border of the channel, outside the Hediste diversicolor bed and called 'Outside' (i.e. not bioturbated by $H$. diversicolor); and (2) inside the worm bed and called 'Inside' (Fig. 1). Burrow walls were sampled $(1 \mathrm{~g})$ by digging up a block of sediment at low tide and scrapping the sediment from the burrow wall (0 to $3 \mathrm{~mm}$ ) using a sterile spatula; these sediments were called 'Wall' (Fig. 1). Samples were placed in sterile bags on ice for transport to the laboratory.

Bacterial counts. FLB and AB were extracted from 3 replicate subsamples of the homogenized gut, feces and sediment samples. FLB were extracted from samples (complete sample for the gut and feces, $1 \mathrm{~g}$ for out- 
side and inside sediments and $0.3 \mathrm{~g}$ for wall sediment) by washing with $10 \mathrm{ml}$ of sterile artificial seawater. After agitation for $10 \mathrm{~min}$ at $150 \mathrm{rpm}$, the sediment slurry was centrifuged $15 \mathrm{~min}$ at $500 \mathrm{~g}$. Supernatants were kept for direct counts and RNA extraction of FLB. $\mathrm{AB}$ were extracted from sediment pellets according to Lucas et al. (1996). Briefly, the pellets were sonicated for 10 min with $200 \mathrm{mg}$ of Chelex 100 (Bio-Rad) and $10 \mathrm{ml}$ of $0.1 \%$ sodium deoxycholate and $2.5 \%$ PEG 6000 solution. After centrifugation, supernatants were kept for direct counts and RNA extraction of AB. Bacteria in supernatants were stained with acridine orange and were counted using an epifluorescence microscope (Hobbie et al. 1977). Counts were reported as average number per $g$ of dry sediment (DW). Statistical comparison of densities was conducted using multivariate analysis of variance and Tukey's multiple comparison tests (Statgraphics, Manugistics).

5S rRNA extraction and labeling. The small amount of sample we collected from the burrow wall and gut contents did not allow us to obtain enough cells for RNA extraction. As a consequence, RNA was only extracted from outside and inside samples. FLB and $\mathrm{AB}$ were collected from supernatants by centrifugation for $10 \mathrm{~min}$ at $10000 \times \mathrm{g}$. RNA was extracted from bacterial biomass according to Tsai et al. (1991), slightly modified by adding $20 \%$ polyvinylpolypyrolidone at the beginning of the procedure. Crude extracts were then purified using Qiagen-100 columns (Qiagen SA). One to $4 \mu \mathrm{g}$ of total RNA was mixed with $10 \mu \mathrm{l}$ of buffered T4 RNA-ligase $\left(0.5 \mathrm{U} \mathrm{\mu l}^{-1}\right.$, Pharmacia) and were $3^{\prime}$-end labeled with $10 \mu \mathrm{Ci}(0.37 \mathrm{MBq})$ of [5'-32P]cytidine $3^{\prime}, 5^{\prime}$ diphosphate (specific activity: $3000 \mathrm{Ci}$ $\mathrm{mmol}^{-1}$, Amersham), according to England et al. (1980). Samples were kept overnight at $-20^{\circ} \mathrm{C}$, then they were precipitated with ethanol.
Separation of 5S rRNA and quantitative analysis. Radioactively labeled 5S rRNA was separated using denaturing high power electrophoresis on a $10 \%$ polyacrylamide gel (Sequigel electrophoresis: $380 \times 800 \times$ $0.4 \mathrm{~mm}$, Bio-Rad) according to Höfle (1992). Electrophoresis conditions included stepwise increase over $5 \mathrm{~h}$ from 100 to $250 \mathrm{~W}$. After electrophoresis, the gel was fixed in $1 \%$ acetic acid for 30 min, washed with distilled water and air dried. 5S rRNA profiles were revealed by exposure to X-ray film for $30 \mathrm{~min}$ to several hours. Some samples failed to give band profiles: outside sediment from October 1996 and inside sediment from August 1996 for FLB assemblages; outside sediment from January 1996 for AB.

5S rRNA profiles were standardized and analyzed using Gelcompar (Applied Maths, BVBA) computer software. The relative number of nucleotides and the intensity of each 5S rRNA band was estimated by reference to standards (Escherichia coli 5S rRNA) and the relative intensity of each band per sample was calculated as percentage of total band intensity (area under the densitometric profile). For diversity and similarity analyses, only bands with relative intensity $>4 \%$ were used. Complete profiles are given in Table 1. Each band of different size is considered as an operative taxonomic unit (OTU). Specific diversity was estimated using the Shannon index (Shannon \& Weaver 1963):

$$
H^{\prime}=\sum_{s}^{i=1} p_{i} \times \log _{2} p_{i} \quad\left(p_{i}=n_{i} / N\right)
$$

where $N$ is the total intensity of 5S rRNA per sample and $n_{i}$ the intensity for each band (Lucas 1997, Höfle et al. 1999). The Shannon index increases with the number of species and is balanced by the frequency of each species (Shannon \& Weaver 1963).

Table 1. Relative intensity of 5S rRNA bands (percentage of the total amount of 5S rRNA sample) for free-living (FLB) and attached bacteria (AB) in outside and inside sediments, in October 1995 (O95) and January (J96), May (M96), August (A96) and October (O96) 1996. Each band represents an operational taxonomic unit (OTU)

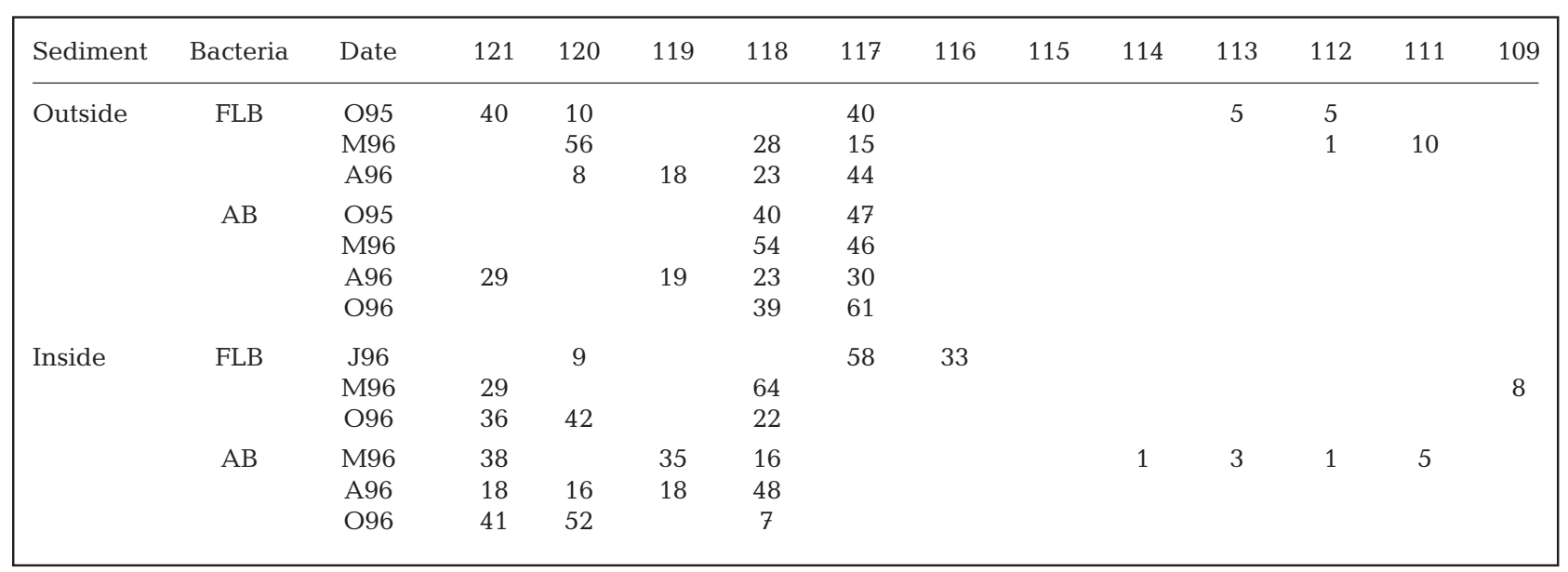


Similarity between samples was calculated using the Sorensen index (Cs; Sorensen 1948), where $j$ is the number of common bands, and $a$ and $b$ the number of bands in the samples A and B: $\mathrm{Cs}=2 j /(a+b)$. A Sorensen value of 1 is expected for identical samples and 0 for dissimilar samples. The Sorensen matrix was compared to binary matrices for the sediment type, the bacterial assemblage and the date. Using the software Fstat 2.9.3.1 (Goudet 1995), partial correlation of the matrices was performed with the Mantel test and a Monte Carlo procedure (5000 permutations) was used to determine statistical significance (Manly 1991).

\section{RESULTS}

\section{Bacterial densities in the digestive tract of Hediste diversicolor}

As shown in Fig. 2A, FLB densities from inside sediment $\left(4.2 \times 10^{8}\right.$ cells $\left.\mathrm{g}^{-1}\right)$ were 27 times lower than $\mathrm{AB}$ densities $\left(115.1 \times 10^{8}\right.$ cells g $\left.^{-1}\right)$. For both bacterial groups, densities were significantly $(n=24, p<0.01)$ lower in the MG samples versus inside sediment (Table 2). Selection and/or digestion of bacteria resulted in a decrease of $81 \%$ for FLB densities and $88 \%$ for $\mathrm{AB}$ densities in $\mathrm{MG}$ (Fig. 2A, Table 3). When comparing HG versus MG, results differed between FLB and $A B$, with a significant ( $\mathrm{n}=24, \mathrm{p}<0.01$ ) increase $(55 \%)$ for FLB and decrease (95\%) for AB (Tables $2 \& 3$ ).
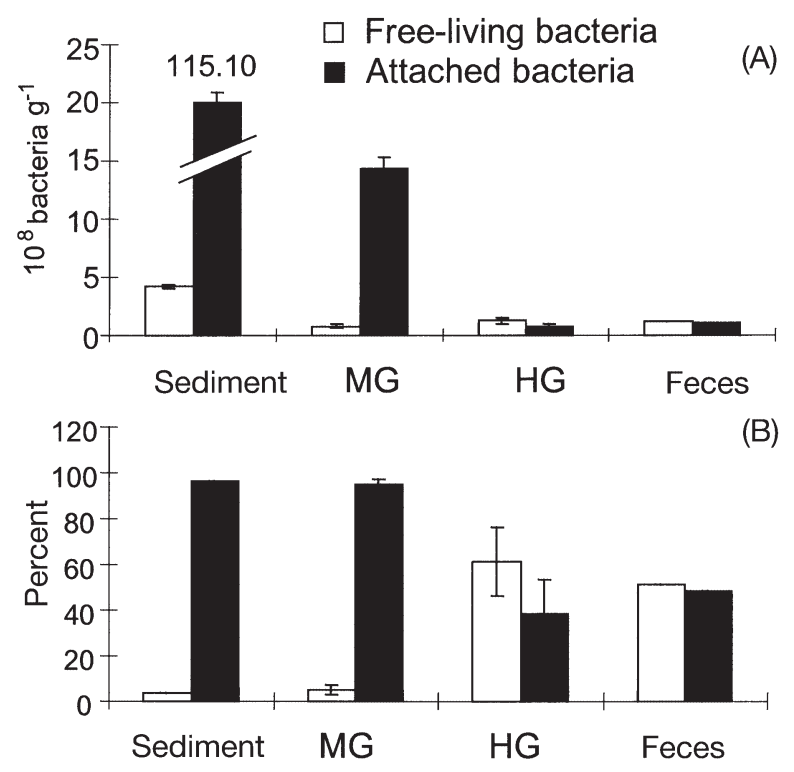

Fig. 2. (A) Bacterial density $\left(10^{8}\right.$ cells $\left.\mathrm{g}^{-1} \mathrm{DW}\right)$ and (B) relative contribution in percent of free-living (FLB) and attached (AB) bacteria in inside sediment, midgut (MG) and hindgut (HG) content, and feces of Hediste diversicolor. Error bars denote $\mathrm{SD}(\mathrm{n}=3)$
Table 2. Variance analysis and Tukey's test $(\mathrm{n}=24, \mathrm{p}<0.01)$ of densities and percent of free-living (FLB) and attached (AB) bacteria in inside sediment, midgut (MG) and hindgut (HG) contents, and feces of Hediste diversicolor. No significant difference was found between the underlined groups

\begin{tabular}{|ccl|}
\hline & Bacteria & \multicolumn{1}{c|}{ Sediment } \\
\hline Density & AB & HG Feces $<$ MG $<$ Sediment \\
Percent & FLB & HG $<$ Feces MG $<$ Sediment \\
& AB & HG Feces $<$ MG Sediment \\
& FLB & Sediment $\mathrm{MG}<$ Feces HG \\
\hline
\end{tabular}

In feces, bacterial abundances were not significantly different from densities in HG samples (Table 2). The increase of $\mathrm{AB}(42.3 \%)$ in the feces was not significant ( $\mathrm{n}=24, \mathrm{p}>0.05)$ due to high SD (Tables $2 \& 3$ ).

\section{Percent of FLB and AB in digestive tract of Hediste diversicolor}

Attached bacteria dominated (94 to $97 \%$ ) the bacterial community in inside sediment and the MG. However, the relative proportions of FLB and AB shifted in the $\mathrm{HG}$ and feces, with $\mathrm{AB}$ representing only 40 to $48 \%$ of the bacterial community (Fig. 2B). FLB content was significantly $(n=24, p<0.01)$ higher in the feces and the $\mathrm{HG}$, while $\mathrm{AB}$ densities were significantly ( $\mathrm{n}=$ 24, $\mathrm{p}<0.01$ ) higher in inside sediment and MG than in HG and feces (Table 2). There was no significant difference between HG and the feces for both bacterial fractions (Table 2).

\section{Bacterial densities in outside and inside sediments}

Bacterial densities from outside, inside and wall sediments are reported in Fig. 3. FLB densities ranged from 0.7 to $16.2 \times 10^{8}$ cells g ${ }^{-1}$ (Fig. $3 \mathrm{~A}$ ) and $\mathrm{AB}$ densities ranged from 36.7 to $284.2 \times 10^{8}$ cells g $^{-1}$ (Fig. 3B).

\section{Seasonal variations}

FLB concentrations increased in January 1996 $\left(16.2 \times 10^{8}\right.$ cells g $\left.^{-1}\right)$ and May $1996\left(9.6 \times 10^{8}\right.$ cells g $\left.{ }^{-1}\right)$ in the inside sediments. In outside sediments, FLB densities peaked in May $1996\left(11.9 \times 10^{8}\right.$ cells g $\left.^{-1}\right)$ and for the wall sediments, the FLB abundances were higher in August 1996 (Fig. 3A). FLB densities in May 1996 were significantly higher than in October 1995 and 1996, and August 1996 (Table 4). Percentage of FLB significantly increased in January and May 1996 and was highest in May 1996 ( $\mathrm{n}=42, \mathrm{p}<0.01)$. 
Table 3. Change in proportion of free-living (FLB) and attached $(\mathrm{AB})$ bacteria densities along the digestive tract of Hediste diversicolor (difference between average density of Sample 1 in comparison to Sample 2)

\begin{tabular}{|lrr|}
\hline Difference between 2 samples & FLB & \multicolumn{1}{c|}{ AB } \\
\hline Midgut content vs inside sediment & -80.7 & -87.5 \\
Hindgut vs midgut content & 55.0 & -94.5 \\
Feces vs hindgut content & -4.8 & 42.3 \\
\hline
\end{tabular}

AB densities increased in October 1995 and August 1996 in the 3 sediments, with maximum densities ranging from 76.5 to $283.6 \times 10^{8}$ cells g ${ }^{-1}$ (Fig. 3B). The lowest densities were reported in January 1996 with $39.6 \times 10^{8}$ cells g $^{-1}$ in outside sediment, $36.7 \times 10^{8}$ cells $\mathrm{g}^{-1}$ in inside sediment and $49.9 \times 10^{8}$ cells g $^{-1}$ in burrow walls. AB increase in October 1995 and August 1996 was significant (Table 4). The percent of $A B$ was significantly higher in October 1995, August 1996 and October 1996 ( $\mathrm{n}=42, \mathrm{p}<0.01$; Table 4).

\section{Differences between sediments}

In outside sediments, the FLB densities ranged from 2.3 to $16.2 \times 10^{8}$ cells g $^{-1}$ (Fig. 3A). Densities were lower in inside sediments $\left(0.3\right.$ to $11.9 \times 10^{8}$ cells g $\left.^{-1}\right)$ and burrow walls $\left(0.3\right.$ to $8.3 \times 10^{8}$ cells $\left.\mathrm{g}^{-1}\right)$. FLB densities were significantly higher in outside sediments than inside and wall sediments (Table 4). There was no significant difference between the FLB abundances from inside and wall sediments. However, the percentage of FLB was significantly lower in wall sediments than inside sediments (Table 4).

$\mathrm{AB}$ densities were the highest in burrow walls (49.9 to $284.2 \times 10^{8}$ cells $^{-1}$ ) and outside sediments (39.6 to $246.0 \times 10^{8}$ cells g $^{-1}$ ). AB abundances were lower in inside sediments, ranging from 36.7 to $115.1 \times 10^{8}$ cells g $^{-1}$ (Fig. 3B). AB densities from inside sediments were significantly lower than from wall and outside sediments (Table 4). The percentage of AB was significantly higher in the burrow walls and significantly lower in the outside sediments (Table 4).

\section{Analysis of 5S rRNA profiles from outside and inside sediments}

Fig. 4 shows the contribution of bands with a relative intensity $>4 \%$ to each profile. FLB and AB were characterized by a low number of OTUs as indicated by the number of bands of different size (in average 2 to 5 bands
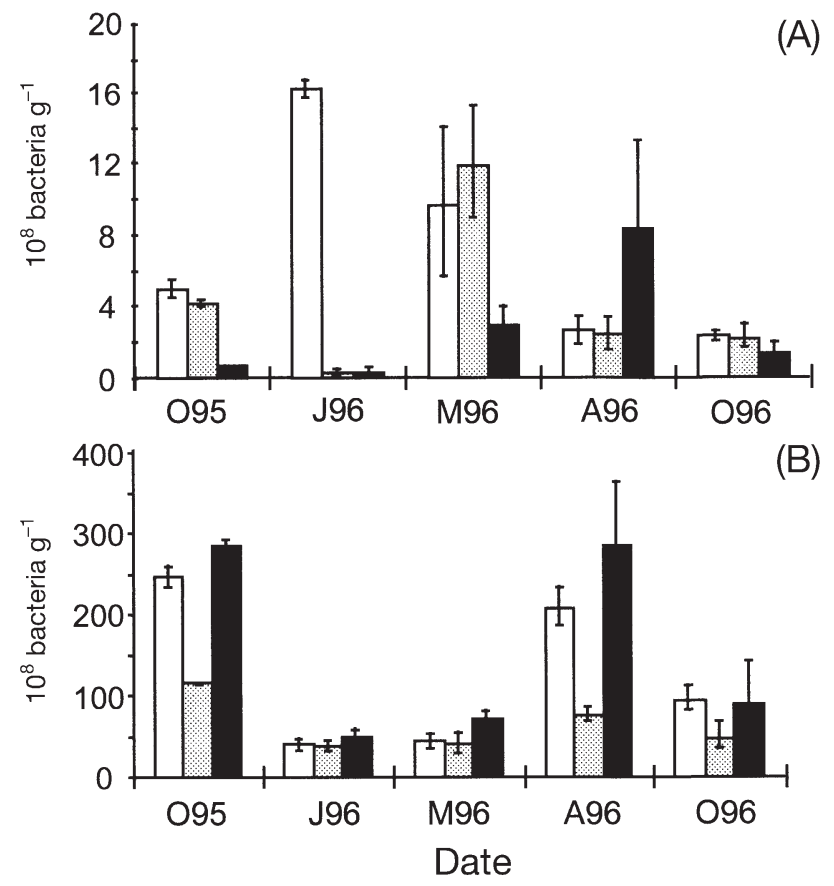

Outside sediment Inside sediment

Burrow wall

Fig. 3. (A) Number of free-living (FLB) and (B) attached (AB) bacteria in outside, inside and burrow wall sediment, according to the sampling date. Error bars denote SD $(n=3)$

per sample; Fig. 4). Analysis of 5S rRNA profiles are limited to the active part of the community, which may explain the low number of OTUs observed in our sediment samples. In all the samples, a total of 12 different bands was recognized, ranging from 109 to 121 nucleotides (nt) in size. Major bands contained 115 to 121 nt (Fig. 4). The Shannon index of 5S rRNA profiles varied from 0.96 to 1.98. As reported in Table 5, the FLB assemblage had a higher average Shannon index $(1.77 \pm 0.05)$ than $\mathrm{AB}(1.32 \pm 0.47)$ in the outside sediment. However, in the inside sediment, the average Shannon index was lower for FLB $(1.34 \pm 0.16)$ than for $\mathrm{AB}(1.60 \pm 0.28)$. There was no significant difference between FLB and AB (ANOVA: $F_{1,12}=0.27, \mathrm{p}=0.61$ ), there was no significant difference between outside

Table 4. Variance analysis and Tukey's test $(\mathrm{n}=42, \mathrm{p}<0.01)$ of densities and percent of free-living (FLB) and attached (AB) bacteria in outside, inside and burrow wall sediments. Underlined groups do not show significant differences

\begin{tabular}{|cclc|}
\hline \multirow{3}{*}{ Bacteria } & Sediment & Season \\
\hline Density & FLB & Wall Inside $<$ Outside & $\underline{\text { O96 O95 A96 J96 M96 }}$ \\
& AB & Inside $<$ Outside Wall & $\underline{\text { J96 M96 O96 }}<\underline{\text { A96 O95 }}$ \\
Percent & FLB & Wall $<$ Inside $<$ Outside & $\underline{\text { O96 O95 A96 }<\text { J96 }<\text { M96 }}$ \\
& AB & Outside $<$ Inside $<$ Wall & M96 < J96 < O96 A96 O95 \\
\hline
\end{tabular}


(A)

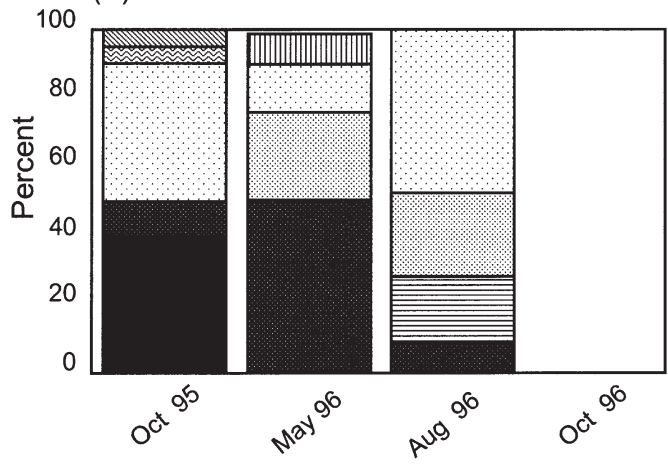

(B)

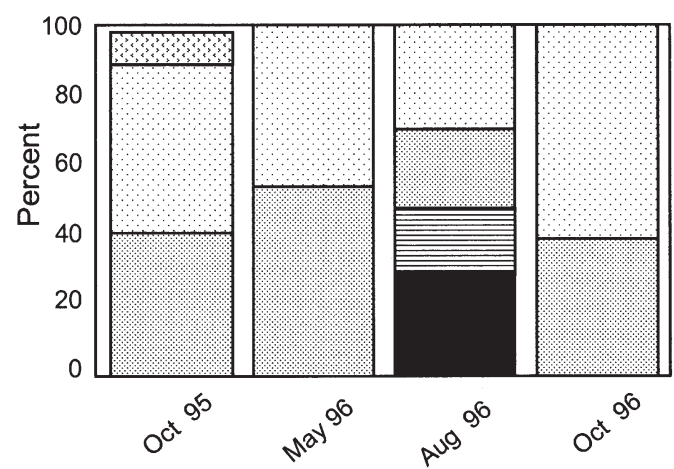

(C)

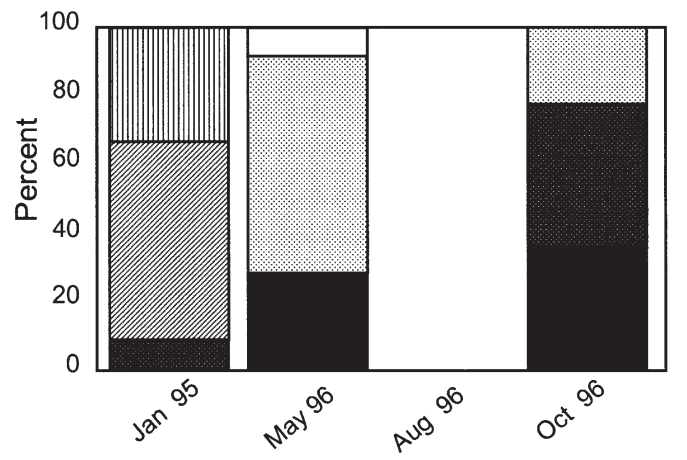

(D)

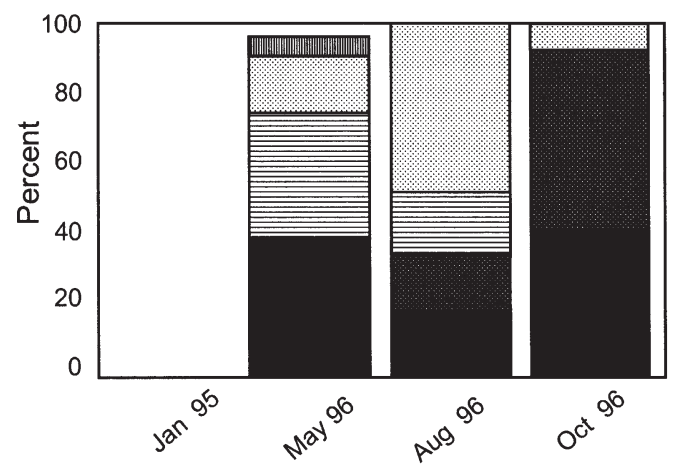

Fig. 4. 5S rRNA profiles for free-living and attached bacteria in $(A, B)$ outside and $(C, D)$ inside sediments, respectively. The relative contribution of each band per sample is expressed as a percent of the total amount of $5 \mathrm{~S}$ rRNA in the sample (bands $<4 \%$ are not represented). The size of the bands is expressed in nucleotides (nt)

and inside sediments $\left(F_{1,12}=0.16, \mathrm{p}=0.69\right)$. The interaction between the bacterial fraction and the sediment type was not significant $\left(F_{3,12}=4.00, \mathrm{p}=0.08\right)$. Given the low number of samples, the validity of the statistical tests has to be taken with caution.

The structure of FLB and AB assemblages was compared using the Sorensen index (Table 6). To simplify the analysis, we used the Mantel test. However, these results have to be interpreted with caution because of the low number of samples being compared. Also, the Mantel test masked the dynamic aspect of the assemblages. For the structure of both FLB and AB, there was a significant difference between outside and inside

Table 5. Overall diversity, expressed as Shannon index of free-living (FLB) and attached $(\mathrm{AB})$ bacteria in outside and inside sediments based on 5S rRNA community fingerprints. nd: not determined

\begin{tabular}{|lccccccc|}
\hline Sediment & Bacteria & O95 & J96 & M96 & A96 & O96 & Average \pm SD \\
\hline Outside & FLB & 1.82 & nd & 1.73 & 1.75 & nd & $1.77 \pm 0.05$ \\
& AB & 1.35 & nd & 1.00 & 1.98 & 0.96 & $1.32 \pm 1.47$ \\
Inside & FLB & nd & 1.30 & 1.19 & nd & 1.54 & $1.34 \pm 0.16$ \\
& AB & nd & nd & 1.70 & 1.82 & 1.29 & $1.60 \pm 0.28$ \\
\hline
\end{tabular}

sediments (Table 7). However, in August 1996, AB assemblages from inside and outside sediments shared similar structures (Sorensen index of 0.75 ; Table 6 ).

There was no significant correlation between the bacterial structure and the sampling date (Table 7). The structure of $\mathrm{AB}$ assemblages seemed more stable over the time period sampled than the FLB fraction, especially in outside sediment. In this sediment, the 117 and 118 bp OTUs dominated the AB community at each sampling date (Fig. 4). When comparing samples of the same sediment on different dates, $A B$ Sorensen indices varied from 0.57 to 1.00 , while FLB Sorensen indices ranged from 0.00 to 0.75 (Table 6).

The structure of FLB assemblages was not different from the structure of $\mathrm{AB}$ assemblages (Table 7). AB and FLB structure mostly differed in low molecular weight bands (109 to $116 \mathrm{nt}$ ), which appeared in January and May (Fig. 4, Table 1). In August and October, the FLB and $A B$ assemblages were dominated by medium size bands (117 to $120 \mathrm{nt}$ ) or high molecular weight bands (121 nt). The Sorensen matrix 
Table 6. Sorensen index of free-living (FL) and attached (A) bacteria from outside (O) and inside (I) sediments in October 1995 (O95), January (J96), May (M96), August (A96) and October (O96) 1996

\begin{tabular}{|c|c|c|c|c|c|c|c|c|c|c|c|c|}
\hline & OFLO95 & OFLM96 & OFLA96 & OAO95 & OAM96 & OAA96 & OAO96 & IFLJ96 & IFLM96 & IFL096 & IAM96 & IAA96 \\
\hline OFLM96 & 0.44 & & & & & & & & & & & \\
\hline OFLA96 & 0.44 & 0.75 & & & & & & & & & & \\
\hline OAO95 & 0.25 & 0.86 & 0.57 & & & & & & & & & \\
\hline OAM96 & 0.29 & 0.67 & 0.67 & 0.80 & & & & & & & & \\
\hline OAA96 & 0.44 & 0.5 & 0.75 & 0.57 & 0.67 & & & & & & & \\
\hline OAO96 & 0.29 & 0.67 & 0.67 & 0.80 & 1.00 & 0.67 & & & & & & \\
\hline IFLJ96 & 0.25 & 0.29 & 0.29 & 0.00 & 0.00 & 0.00 & 0.00 & & & & & \\
\hline IFLM96 & 0.00 & 0.29 & 0.29 & 0.33 & 0.40 & 0.57 & 0.40 & 0.00 & & & & \\
\hline IFL096 & 0.50 & 0.57 & 0.57 & 0.33 & 0.40 & 0.57 & 0.40 & 0.33 & 0.67 & & & \\
\hline IAM96 & 0.22 & 0.50 & 0.50 & 0.29 & 0.33 & 0.75 & 0.33 & 0.00 & 0.57 & 0.57 & & \\
\hline IAA96 & 0.44 & 0.50 & 0.75 & 0.29 & 0.33 & 0.75 & 0.33 & 0.29 & 0.57 & 0.86 & 0.75 & \\
\hline IAO96 & 0.50 & 0.57 & 0.57 & 0.29 & 0.40 & 0.57 & 0.40 & 0.33 & 0.67 & 1.00 & 0.57 & 0.86 \\
\hline
\end{tabular}

showed that FLB and AB similarity varied with the sampling period, for example in October 1995, FLB and $A B$ structure were very dissimilar (Table 6). Sorensen indices comparing FLB to AB structures ranged from 0.25 to 0.75 in outside sediments and 0.57 to 1.00 in inside sediments.

\section{DISCUSSION}

In the Bay of Mont St Michel, the polychaete Hediste diversicolor is among the most abundant macroinvertebrates in the salt marsh drainage channels (field observation). This worm has various feeding strategies, including deposit-feeding (Esselink \& Zwarts 1989). As a deposit-feeder, $H$. diversicolor may have a great impact on the microbial community by grazing sediment bacteria.

Most sediment bacteria are attached to sediment grains or other large particles (Dye 1983, Ellery \& Schleyer 1984, Ozawa \& Yamaguchi 1986), which makes them more available to macrofaunal grazers (Plante \& Shriver 1998). In our study, we found that AB represented 76.9 to $99.2 \%$ of the total bacterial community in sediment inside the worm bed. In the digestive tract of Hediste diversicolor, we observed that $81 \%$ of FLB and $88 \%$ of $\mathrm{AB}$ were removed in the MG in comparison to surficial sediment. This finding is in agreement with previous studies reporting removal of more than $50 \%$ of total bacteria with each passage through the gut of various polychaetes (Cammen 1980, Duchêne et al. 1988, Grossmann \& Reichardt 1991, Lucas \& Bertru 1997). Our data also allowed a differentiation between digestive and post-digestive processes. The number of FLB showed a $55 \%$ increase in the HG compared to the MG, while AB continued to decrease. As a result, the prevalent bacterial fraction in the HG and feces shifted to FLB.
The variation of bacterial densities through the gut may have different reasons: (1) sediment sorting; (2) digestion; and (3) bacterial growth and contribution by the gut flora (Dobbs \& Guckert 1988b, Plante et al. 1989). Sediment sorting may have played a significant role in altering the bacterial community as Hediste diversicolor enriches its intake in organic matter versus inorganic sediment particles (Gunnarsson et al. 1999). However, such a process will enrich the bacterial community in the animal gut (Lopez \& Levinton 1987) and not decrease the bacterial densities. Bacterial digestion can certainly explain the decrease we observed since high bacteriolytic activities were measured in the MG of $H$. diversicolor (Lucas \& Bertru 1997). A shift in the relative proportion of FLB and $\mathrm{AB}$ in the $H$. diversicolor HG can be explained by a rapid growth of FLB using digestion products (Plante et al. 1989) or by AB becoming free after the action of digestive enzymes. Differential fate of FLB versus $A B$ in the gut could be explained by taxonomic differences, although there is no clear consensus on this matter in the literature (Hollibaugh et al. 2000). Differential lysis of diverse bacterial taxa has been reported previously. Plante \& Shriver (1998) demonstrated in vitro that Grampositive bacteria are more resistant to bacteriolysis by Arenicola marina MG fluids, and some studies have demonstrated in situ changes of bacterial community

Table 7. Partial correlation (Mantel test, $\mathrm{n}=78$ ) between the Sorensen matrix and bacterial, spatial and temporal data.

Values in bold represent significant correlation $(p<0.05)$

\begin{tabular}{|lcc|}
\hline Factor & $\mathrm{R}$ & $\mathrm{p}$ \\
\hline Sediment & $\mathbf{0 . 4 2 6}$ & $\mathbf{0 . 0 1 0}$ \\
Sampling date & 0.110 & 0.238 \\
Bacterial assemblage & 0.023 & 0.544 \\
Bacterial density & 0.058 & 0.777 \\
\hline
\end{tabular}


structure between ingested sediment, guts and feces (Duchêne et al. 1988, Dobbs \& Guckert 1988b).

The changes in bacterial community structure that we documented in the Hediste diversicolor digestive tract may also affect the bacterial diversity in surrounding sediments. The effect depends on the abundance, feeding rate and digestive efficiency of depositfeeders, relative to the bacterial growth rates (Plante \& Shriver 1998). Biotic processes, such as irrigation activity, material translocation and mucus secretion by the polychaete, as well as abiotic processes, such as wave action, sediment reworking, organic matter deposition, groundwater seeping, seasonal variation of sediment $\mathrm{pH}$, temperature and moisture, can also overshadow the effect of gut processing.

In our study, the most pronounced impact of Hediste diversicolor on the sediment bacterial community appeared in the burrow wall. The proportions and densities of $\mathrm{AB}$ in the lining of $H$. diversicolor were significantly higher than in outside and inside sediments. The dominance of $\mathrm{AB}$ in the burrow wall was probably due to the adhesive capacities of the mucus that cover its body and the burrow walls. Moreover, mucus secretion and excretion of urea and ammonium by the worm may also stimulate the growth and activity of bacteria, together with its irrigation activity (Reichardt 1988). Investigation of burrow microbial community structure was complicated by the small amount of material sampled. However, the 5S rRNA profiles that we obtained from total RNA extraction (not divided into FLB and $\mathrm{AB}$ ) showed that the burrow wall community was stable over time and different from assemblages in outside and inside sediments (Lucas 1997). In terms of physico-chemical characteristics, infaunal burrow walls are fairly stable environments compared to the more frequently disturbed sediment/water interface (Steward et al. 1996). This stability over time allows for the development of complex microbial biofilms (Steward et al. 1996, Phillips \& Lovell 1999). It leads to the formation of microbial communities fundamentally different from the nearby surface and subsurface sediments, with substantial bacterial diversity and high bacterial densities and growth rates (Steward et al. 1996, Dobbs \& Guckert 1988a).

In surficial sediments, disturbance due to Hediste diversicolor burrowing and movement, as well as sediment mixing by physical processes (tidal or wave action, ripple migration) could have major impacts on densities and taxonomic structure of FLB and AB fractions. These processes may activate or stimulate the bacteria that would otherwise be slow growing or dormant (Findlay et al. 1990). In our study, FLB and AB densities were significantly lower in inside sediment than in outside sediment. We found it difficult to separate $H$. diversicolor activity or seasonal changes versus tidal flow within the channel or other disturbance to explain the changes in bacterial densities. Grain size analysis of outside and inside samples did not show any significant differences (data not shown). However, the high densities of bacteria in the undisturbed creek bank sediments may be explained by groundwater seepage, which is likely responsible for the 2 to 3 times higher carbon and nitrogen concentrations measured in the groundwater of the channel border compared to the channel water (Troccaz 1996). These nutrient rich conditions surely contributed to the difference in inside sediment situated in the middle of the channel.

FLB and $A B$ densities in outside and inside sediments did not covary, suggesting that these 2 fractions responded to different environmental factors. The structure of the $\mathrm{AB}$ assemblages in the channel sediment seemed more stable throughout the year than the FLB structure. Attachment to particles may provide a more stable environment and protection against protozoan and meiofaunal grazing. Moreover, biofilms that cover surfaces also provide the opportunity for developing stable mutualistic interactions among the microbiota.

There was no taxonomic difference between the 2 fractions in the channel sediments. Other studies using fingerprinting methods (5S rRNA profiles and 16S rDNA DGGE profiles, respectively) also reported that FLB and AB assemblages in estuarine waters were similar (Bidle \& Fletcher 1995, Hollibaugh et al. 2000, Selje \& Simon 2003). These 2 assemblages of bacteria should be considered as interacting entities. Many exchanges can occur between these 2 groups via adsorption and desorption phenomena (Bright \& Fletcher 1983, Karner \& Herndl 1992). However, several studies using cloning methods suggest high taxonomic differences between FLB and AB assemblages (Delong et al. 1993, Acinas et al. 1999, Crump et al. 1999). The discrepancy between these reports may come from methodological biases, resulting in the analysis of different subsets of the total bacterial community. Firstly, these studies often used different methods to separate FLB from AB (Selje \& Simon 2003). Secondly, fingerprint bands of similar position may represent completely different clones. Other important factors in determining the relative composition of $\mathrm{AB}$ and FLB assemblages may be the composition of the particle organic matter (Hollibaugh et al. 2000) and/or the ratio of organic and inorganic material in the sample (Selje \& Simon 2003). The huge variation in similarity indices between FLB and AB assemblages that we found according to the sampling date may also be explained by variation in the quality of the organic matter.

This study showed that in sediment, FLB and AB can also be considered as interacting populations that have 
different dynamics in response to the presence of Hediste diversicolor and seasonal variation. Separation of FLB and AB was useful in studying the relationship between sediment bacteria and macrofauna. However, further studies will help to elucidate the relative importance of abiotic versus biotic effects on spatial and temporal distribution of bacteria and the taxonomic structure of the sediment bacterial community. Estimation of bacterial production and rate of sediment turn-over due to $H$. diversicolor feeding and defecation will also be useful for knowing how important these processes are in regulating bacterial densities and structure.

Acknowledgements. We thank V. Créach for her help during sample collection. We are grateful to K. Dominik, I. Fritz, K. Seikowsky and S. Pretzer for their help with 5S rRNA analysis electrophoresis. Comments on this manuscript by C. Simenstad (University of Washington), J. T. Hollibaugh (University of Georgia) and anonymous reviewers are greatly appreciated. This work was supported by a grant from the European Community (DGXII, \#E5V-0098) awarded to J.C.L.

\section{LITERATURE CITED}

Acinas SG, Anton J, Rodriguez-Valera F (1999) Diversity of free-living and attached bacteria in offshore western Mediterranean waters as depicted by analysis of genes encoding 16S rRNA. Appl Environ Microbiol 65:514-522

Aller RC, Yingst JY (1985) Effects of the marine depositfeeders Heteromastus filiformis (Polychaeta), Macoma balthica (Bivalvia), and Tellina texana (Bivalvia) on averaged sedimentary solute transport, reaction-rates, and microbial distributions. J Mar Res 43:615-645

Amann RI, Ludwig W, Schleifer KH (1995) Phylogenetic identification and in situ detection of individual microbial cells without cultivation. Microbiol Rev 59:143-169

Azam F, Fenchel T, Field JG, Gray JS, Meyer-Reil LA, Thingstad F (1983) The ecological role of water column microbes in the sea. Mar Ecol Prog Ser 19:257-272

Bidle KD, Fletcher M (1995) Comparison of free-living and particle-associated bacterial communities in the Chesapeake Bay by stable low-molecular-weight RNA analysis. Appl Environ Microbiol 61:944-952

Bird FL, Boon PI, Nichols PD (2000) Physicochemical and microbial properties of burrows of the deposit-feeding thalassinidean ghost shrimp Biffarius arenosus (Decapoda: Callianassidae). Estuar Coast Shelf Sci 51:279-291

Bright JJ, Fletcher M (1983) Amino acid assimilation and electron transport system activity in attached and free-living marine bacteria. Appl Environ Microbiol 45:818-825

Cammen LM (1980) The significance of microbial carbon in the nutrition of the deposit feeding polychaete Nereis succinea. Mar Biol 61:9-20

Crump BC, Armbrust EV, Baross JA (1999) Phylogenetic analysis of particle-attached and free-living bacterial communities in the Columbia River, its estuary, and the adjacent coastal ocean. Appl Environ Microbiol 65: 3192-3204

Delong EF, Franks DG, Alldredge AL (1993) Phylogenetic diversity of aggregate-attached vs free-living marine bacterial assemblages. Limnol Oceanogr 38:924-934

Dobbs FC, Guckert JB (1988a) Callianassa trilobata (Crustacea, Thalassinidea) influences abundance of meiofauna and biomass, composition, and physiological state of microbial communities within its burrow. Mar Ecol Prog Ser 45:69-79

Dobbs FC, Guckert JB (1988b) Microbial food resources of the macrofaunal deposit-feeder Ptychodera bahamensis (Hemichordata: Enteropneusta). Mar Ecol Prog Ser 45: 127-136

Duchêne JC, Imbaud P, Delille D (1988) Associated bacterial microflora of a subantarctic polychaete worm Thelepus setosus. Arch Hydrobiol 112:221-231

Dye AH (1983) A method for the quantitative estimation of bacteria from mangrove sediments. Estuar Coast Shelf Sci $17: 207-212$

Ellery WN, Schleyer MH (1984) Comparison of homogenization and ultrasonication as techniques in extracting attached sedimentary bacteria. Mar Ecol Prog Ser 15: $247-250$

England TE, Bruce AG, Uhlenbeck OC (1980) Specific labeling of $3^{\prime}$ termini of RNA with T4 RNA ligase. Methods Enzymol 65:65-85

Esselink P, Zwarts L (1989) Seasonal trend in burrow depth and tidal variation in feeding activity of Nereis diversicolor. Mar Ecol Prog Ser 56:243-254

Findlay RH, White DC (1983) The effects of feeding by the sand dollar Mellita quinquiesperforata (Leske) on the benthic microbial community. J Exp Mar Biol Ecol 72:25-41

Findlay RH, Trexler MB, Guckert JB, White DC (1990) Laboratory study of disturbance in marine-sedimentresponse of a microbial community. Mar Ecol Prog Ser 62: 121-133

Gilbert F, Rivet L, Bertrand JC (1994) The in-vitro influence of the burrowing polychaete Nereis diversicolor on the fate of petroleum-hydrocarbons in marine-sediments. Chemosphere 29:1-12

Goudet J (1995) FSTAT Vers. 1.2 , a computer program to calculate F-statistics. J Hered 86:485-486

Grossmann S, Reichardt W (1991) Impact of Arenicola marina on bacteria in intertidal sediments. Mar Ecol Prog Ser 77: 85-93

Gunnarsson JS, Hollertz K, Rosenberg R (1999) Effects of organic enrichment and burrowing activity of the polychaete Nereis diversicolor on the fate of tetrachlorobiphenyl in marine sediments. Environ Toxicol Chem 18: 1149-1156

Hobbie J, Daley RJ, Jasper S (1977) Use of nucleopore filters for counting bacteria by fluorescence microcoscopy. Appl Environ Microbiol 33:1225-1228

Höfle MG (1992) Bacterioplankton community structure and dynamics after large-scale release of nonindigenous bacteria as revealed by low-molecular-weight-RNA analysis. Appl Environ Microbiol 58:3387-3394

Höfle MG, Haas H, Dominik K (1999) Seasonal dynamics of bacterioplankton community structure in a eutrophic lake as determined by 5S rRNA analysis. Appl Environ Microbiol 65:3164-3174

Hollibaugh JT, Wong PS, Murrell MC (2000) Similarity of particle-associated and free-living bacterial communities in northern San Francisco Bay, California. Aquat Microb Ecol 21:103-114

Karner M, Herndl GJ (1992) Extracellular enzymatic activity and secondary production in free-living and marinesnow-associated bacteria. Mar Biol 113:341-347

Kemp P (1990) The fate of benthic bacterial production. Aquat Sci 2:109-124

Kemp P, Lee S, LaRoche J (1993) Estimating the growth rate of slowly growing marine bacteria from RNA content. Appl Environ Microbiol 59:2594-2601 
Lopez GR, Levinton JS (1987) Ecology of deposit-feeding animals in marine sediments. Q Rev Biol 62:235-260

Lucas F (1997) Activité et structure de la communauté bactérienne des sédiments colonisés par Nereis diversicolor (O.F. Müller). PhD thesis, Université de Rennes 1

Lucas F, Bertru G (1997) Bacteriolysis in the gut of Nereis diversicolor and effect of diet. J Exp Mar Biol Ecol 215: 235-245

Lucas F, Meziane T, Bertru G, Retiere C (1996) Bactéries du sédiment: extraction et distribution sur un estran (Baie du Mont Saint Michel). CR Acad Sci, Série III 319:537-542

Manly BFJ (1991) Randomization and Monte Carlo methods in biology. Chapman \& Hall, London

Moriarty DJW, Pollard PC, Hunt WG, Moriarty CM, Wassenberg TJ (1985) Productivity of bacteria and microalgae and the effect of grazing by holothurians in sediments on a coral reef flat. Mar Biol 85:293-300

Ozawa T, Yamaguchi M (1986) Fractionation and estimation of particle-attached and unattached Bradyrhizobium japonicum strains in soils. Appl Environ Microbiol 52: 911-914

Pedros-Alio C (1989) Toward an autoecology of bacterioplankton. In: Sommer U (ed) Plankton ecology: succession in plankton communities. Springer-Verlag, Berlin, p 297-336

Phillips TM, Lovell CR (1999) Distribution of total and active bacteria in biofilms lining tubes of the onuphid polychaete Diopatra cuprea. Mar Ecol Prog Ser 183:169-178

Plante C, Jumars P (1993) Immunofluorescence assay for effects on field abundance of a naturally-occurring pseudomonad during passage through the gut of a marine deposit-feeder, Abarenicola pacifica. Microbial Ecol 26: $247-266$

Plante CJ, Shriver AG (1998) Differential lysis of sedimentary

Editorial responsibility: James Hollibaugh, Athens, Georgia, USA bacteria by Arenicola marina L.: examination of cell wall structure and exopolymeric capsules as correlates. J Exp Mar Biol Ecol 229:35-52

Plante CJ, Jumars PA, Baross JA (1989) Rapid bacterial growth in the hindgut of a marine deposit-feeder. Microb Ecol 18:29-44

Reichardt W (1988) Impact of the Antarctic benthic fauna on the enrichment of biopolymer degrading psychrophilic bacteria. Microb Ecol 15:311-321

Reichardt W, Piker L, Juterzenka KV, Grossmann S, Bussmann I (1991) Burrowing macrozoobenthos as major determinant of bacteria in sediments. Kiel Meeresforsch Sonderh 8:86-91

Selje N, Simon M (2003) Composition and dynamics of particle-associated and free-living bacterial communities in the Weser estuary, Germany. Aquat Microb Ecol 30:221-237

Shannon CE, Weaver W (1963) The mathematical theory of communication, Vol III. University of Illinois Press, Urbanna, IL

Sorensen T (1948) A method of establishing groups of equal amplitude in plant sociology based on similarity of species content. Biol Skr 4:1-34

Steward CC, Nold SC, Ringelberg DB, White DC, Lovell CR (1996) Microbial biomass and community structures in the burrows of bromophenol producing and non-producing marine worms and surrounding sediment. Mar Ecol Prog Ser 133:149-165

Troccaz O (1996) Evolution de la dynamique d'un marais salé: processus fonctionnels internes et relations avec le milieu côtier: la Baie du Mont Saint Michel. Mémoire de diplôme doctoral de recherches, Université de Rennes 1

Tsai YL, Park MJ, Olson BH (1991) Rapid method for direct extraction of mRNA from seeded soils. Appl Environ Microbiol 57:765-768

Submitted: September 15, 2000; Accepted: January 21, 2003 Proofs received from author(s): May 16, 2003 